\title{
Association of intrathecal pleocytosis and IgG synthesis with axonal damage in early MS
}

Sinah Engel, Falk Steffen, Timo Uphaus, MD, Peter Scholz-Kreisel, PhD, Frauke Zipp, MD, Stefan Bittner, MD, * and Felix Luessi, MD*

Neurol Neuroimmunol Neuroinflamm 2020;7:e679. doi:10.1212/NXI.0000000000000679
Correspondence

Dr. Luessi

luessi@uni-mainz.de

\section{Abstract}

\section{Objective}

To investigate the association of serum neurofilament light chain (sNfL) levels with CSF parameters in clinically isolated syndrome (CIS) and early relapsing-remitting MS (RRMS), taking into account radiologic and clinical parameters of disease activity.

\section{Methods}

Simultaneously collected serum and CSF samples of 112 untreated patients newly diagnosed with CIS or RRMS were included in this cross-sectional study. CSF parameters were obtained as part of routine diagnostic tests. sNfL levels of patients and of 62 healthy donors were measured by highly sensitive single molecule array ( $\mathrm{SiMoA})$ immunoassay.

\section{Results}

Patients with RRMS ( $\mathrm{n}=91$, median $10.13 \mathrm{pg} / \mathrm{mL}$, interquartile range [IQR] 6.67-17.77 pg/ $\mathrm{mL})$ had higher sNfL levels than healthy donors $(\mathrm{n}=62$, median $5.25 \mathrm{pg} / \mathrm{mL}$, IQR 4.05-6.81 $\mathrm{pg} / \mathrm{mL}, p<0.001)$ and patients with CIS ( $\mathrm{n}=21$, median $5.69 \mathrm{pg} / \mathrm{mL}$, IQR 4.73-9.07 pg/mL, $p<0.001)$. Patients positive for oligoclonal bands (OCBs) $(\mathrm{n}=101$, median $9.19 \mathrm{pg} / \mathrm{mL}, \mathrm{IQR}$ $6.34-16.38 \mathrm{pg} / \mathrm{mL})$ had higher sNfL levels than OCB-negative patients $(\mathrm{n}=11$, median 5.93 $\mathrm{pg} / \mathrm{mL}$, IQR $2.93-8.56 \mathrm{pg} / \mathrm{mL}, p=0.001)$. sNfL levels correlated with CSF immunoglobulin G (IgG) levels $(r=0.317, p=0.002), \operatorname{IgG}$ ratio (QIgG) $(r=0.344, p<0.001)$, and CSF leukocyte count $(r=0.288, p=0.002)$. In linear regression modeling, the CSF leukocyte count combined with the number of contrast-enhancing lesions in MRI predicted sNfL levels best.

\section{Conclusions}

In active MS, sNfL levels correlate with intrathecal pleocytosis and IgG synthesis, indicating that axonal damage is associated with both acute and chronic CNS-intrinsic inflammation.

\footnotetext{
*Equal contribution by senior authors.

From the Department of Neurology (S.E., F.S., T.U., F.Z., S.B., F.L.), Focus Program Translational Neuroscience (FTN), and Immunotherapy (FZI), Rhine-Main Neuroscience Network $\left(\mathrm{rmn}^{2}\right)$, University Medical Center of the Johannes Gutenberg University; and Institute of Medical Biostatistics (P.S.-K.), Epidemiology and Informatics, University Medical Center of the Johannes Gutenberg University, Mainz, Germany.

Go to Neurology.org/NN for full disclosures. Funding information is provided the end of the article.

The Article Processing Charge was funded by the authors.

This is an open access article distributed under the terms of the Creative Commons Attribution-NonCommercial-NoDerivatives License 4.0 (CC BY-NC-ND), which permits downloading and sharing the work provided it is properly cited. The work cannot be changed in any way or used commercially without permission from the journal.
} 


\section{Glossary}

BBB = blood-brain barrier; CEL = contrast-enhancing lesion; CIS = clinically isolated syndrome; EDSS = Expanded Disability Status Scale; IgG = immunoglobulin G; IQR = interquartile range; $\mathbf{O C B}=$ oligoclonal band; $\mathbf{O N}=$ optic neuritis; $\mathbf{N f H}=$ neurofilament heavy chain; $\mathbf{N f L}=$ neurofilament light chain; $\mathbf{s N f L}=$ serum neurofilament light chain; $\mathbf{Q}$ alb $=\mathrm{CSF} / \mathrm{serum}$ albumin ratio; $\mathbf{Q g G}=\mathrm{CSF} /$ serum IgG ratio; RRMS = relapsing-remitting MS.

Neurofilament light chain (NfL) subunits represent one of the main constituents of the neuronal cytoskeleton, which are released into the CSF and, to a lesser extent, into the peripheral blood, following axonal injury. ${ }^{1}$ The development of highly sensitive single molecule array ( $\mathrm{SiMoA})$ technology now enables the detection even of small changes in peripheral NfL concentrations. ${ }^{2}$ As it has been demonstrated recently that serum and CSF NfL levels are highly correlated, ${ }^{3}$ serum neurofilament light chain (sNfL) has emerged as an easily accessible biomarker of neuroaxonal damage. Consequently, the past few years have witnessed a surge in the number of publications on sNfL in a variety of neurologic disorders. ${ }^{2,4}$

In MS, NfL levels increase during relapses and are positively associated with MRI lesion load and the presence of contrastenhancing lesions (CELs). ${ }^{5-7}$ However, recent studies provide little and inconsistent information about the impact of CSF parameters that reflect inflammatory processes within the CNS compartment on NfL levels in the periphery. Therefore, we aimed to investigate the association between sNfL and markers of acute and chronic CNS inflammation assessed by routine CSF diagnostics in patients with MS. To rule out confounding effects of immunosuppressive or immunomodulatory therapies, we only included untreated patients at the time point of diagnosis of clinically isolated syndrome (CIS) or relapsing-remitting MS (RRMS).

Beyond the exclusion of differential diagnoses, CSF analysis is essential in diagnosing MS. Typical CSF findings in MS include a slightly elevated leukocyte count, the presence of mononuclear cells, and of oligoclonal bands (OCBs), elevated immunoglobulin G (IgG) synthesis, and increased synthesis of intrathecally produced immunoglobulins against measles, rubella, and varicella zoster (MRZ) viruses. Because of its prognostic value, the presence of OCBs in CSF has been incorporated into the 2017 revised McDonald criteria for MS diagnosis as a marker of dissemination in time. ${ }^{8}$ The CSF/ serum albumin ratio (Qalb) as a marker of blood-brain barrier (BBB) integrity is mainly within normal ranges, which is in line with the very focal and transient BBB disruption in MS, but may also be elevated in some patients. ${ }^{9,10}$

An increase in the CSF/serum $\operatorname{IgG}$ ratio (QIgG) and the presence of OCBs reflect chronic CNS-intrinsic immune reactions, ${ }^{11}$ whereas the CSF leukocyte count is a dynamic parameter of acute inflammatory activity. ${ }^{12,13}$ We hypothesized that both chronic and acute inflammation influence sNfL levels in patients with MS.

\section{Methods}

\section{Patients and healthy controls}

A cross-sectional cohort $(\mathrm{n}=112)$ was recruited between 2011 and 2018 at the Department of Neurology at the University Medical Center Mainz (Germany). After informed consent was obtained from all patients, paired serum and CSF samples were prospectively collected and stored. Routine spinal tap was performed as part of the diagnostic workup. Inclusion criteria were (1) a new diagnosis of CIS or RRMS (all diagnoses were reclassified according to the 2017 revised McDonald criteria $\left.{ }^{8}\right) ;(2)$ availability of paired serum and CSF samples at the time of diagnosis; (3) availability of demographic and clinical data at the time of diagnosis; (4) availability of brain and preferably also spinal cord MRI data acquired as part of the diagnostic workup at the time of diagnosis; and (5) no immunosuppressive or immunomodulatory treatment before sample collection. Samples from patients who had received steroid treatment before sample collection were excluded. A total of 11 patients with the presence of OCBs in CSF were diagnosed with CIS, as they did not fulfill the criteria for dissemination in space. ${ }^{8}$

In addition, serum samples from 62 healthy controls were collected and stored after informed consent was obtained.

\section{Standard protocol approvals, registrations, and patient consents}

The study was approved by the local ethics committee (number 837.019.10); written informed consent was obtained from all patients.

\section{CSF analyses}

CSF analyses were performed in a standardized fashion as part of routine diagnostic workup. CSF concentrations of albumin (CSF Alb), immunoglobulin (Ig) A (CSF IgA), IgG (CSF $\operatorname{IgG}$ ), and IgM (CSF IgM) were determined with immunonephelometry. Quotients of albumin (QAlb), quotient of IgA (QIgA), quotient of $\operatorname{IgG}(\mathrm{QIgG})$, and quotient of IgM (QIgM) were defined as the ratios of CSF concentrations to the corresponding serum concentrations of these fractions. Detection of OCBs was performed by isoelectric focusing on agarose gel and subsequent immunoblotting using IgGspecific antibody staining. Reference values were considered according to Berlit. ${ }^{14}$

\section{$\mathrm{NfL}$ single molecule array of serum samples}

sNfL of 112 patients with CIS and MS and of 62 healthy donors was measured by SiMoA technology as previously 
described. ${ }^{7}$ Briefly, blood samples were spun at $2000 \mathrm{~g}$ at room temperature for 10 minutes within 2 hours after withdrawal and stored in polypropylene tubes at $-80^{\circ} \mathrm{C}$. Serum NfL was measured by SiMoA HD-1 (Quanterix) using the NF-Light Advantage Kit (Quanterix) according to the manufacturer's instructions. Samples were measured in duplicates, and the intra-assay coefficient of variation of all samples was $4.5 \%$. sNfL measurements were performed in a blinded fashion without information about clinical data.

\section{Statistics}

Continuous variables are described by their median and interquartile range (IQR), and categorical variables by numbers and percentages. Normal distribution was tested using Kolmogorov-Smirnov and Shapiro-Wilk tests for normal distribution. sNfL levels and the CSF leukocyte count were $\log$ transformed to achieve a more normal distribution for subsequent analyses. Yet, for simplicity of notation, we will use the original terms when reporting and discussing results. Comparison of sNfL levels across groups was performed using the Mann-Whitney $U$ test for comparison between 2 groups and 1-way analysis of variance for comparison between 3 or more groups, respectively. Correlation was determined by the Spearman rank correlation coefficient. Age as a confounding factor needs to be taken into account in older patients, as sNfL seems to considerably increase in particular above the age of 60 years with rather stable values in younger patients. ${ }^{15}$ In agreement, in our cohort of considerably young patients (median age 33.5 years, IQR 28-42 years), we found no significant correlation between age $(r=-0.076, p=0.429)$ and sNfL values, and therefore, no age correction was performed. The joint effects of CSF parameters and clinical and radiologic parameters of disease activity on sNfL levels were assessed by regression analysis with forward variable selection (inclusion threshold of 0.5 ). These effects were validated by regression analysis with backward selection (exclusion threshold of 0.01). $p$ Values $<0.05$ were considered statistically significant. Because of the explorative character of the study, no correction for multiple testing was performed. Statistical analyses were performed using SPSS 23.0 software (IBM Corp, Armonk, NY), SAS software 9.4R4 (SAS Institute Inc., Cary, NC), and GraphPad Prism 7.0 for Windows (GraphPad Software; Microsoft, Redmond, WA).

\section{Data availability}

The raw data used in preparation of the figures and tables will be shared in anonymized format on request of a qualified investigator to the corresponding author for purposes of replicating procedures and results.

\section{Results}

\section{Patient characteristics and CSF analysis}

Patient characteristics including demographic, clinical, and MRI parameters are reported in table 1. Briefly, 21 patients with CIS and 91 patients with RRMS (according to the 2017 revised McDonald criteria ${ }^{8}$ ) were included in this study. Of the patients, $70.5 \%$ experienced an acute relapse within 90 days ${ }^{16,17}$ before sample collection; the median time between onset of relapse and spinal tap was 14 days. CELs in MRI at the time of diagnosis were detectable in $44.6 \%$ of the patients. $34.8 \%$ of the patients showed clinical relapse and CELs in MRI, whereas $19.6 \%$ showed neither (figure 1A). $26.6 \%$ of the patients with relapse presented with optic neuritis (ON), $39.2 \%$ with cerebral, and $34.2 \%$ with spinal clinical manifestation. Type of relapse manifestation was defined by clinical presentation and, whenever available, MRI findings.

sNfL levels in patients with RRMS ( $\mathrm{n}=91$, median $10.13 \mathrm{pg}$ ) $\mathrm{mL}$, IQR $6.67-17.77 \mathrm{pg} / \mathrm{mL}$ ) were significantly higher than those of healthy donors matched for sex and age $(\mathrm{n}=62$, median $5.25 \mathrm{pg} / \mathrm{mL}$, IQR $4.05-6.81 \mathrm{pg} / \mathrm{mL}, p<0.001)$ and those of patients with CIS $(\mathrm{n}=21$, median $5.69 \mathrm{pg} / \mathrm{mL}$, IQR 4.73-9.07 pg/mL, $p<0.001$ ) (figure 1B). Within the patient group, we observed no sex-specific differences of sNfL levels (men: $\mathrm{n}=36$, median $10.95 \mathrm{pg} / \mathrm{mL}$, IQR $6.93-16.82 \mathrm{pg} / \mathrm{mL}$; women: $\mathrm{n}=76$, median $8.54 \mathrm{pg} / \mathrm{mL}$, IQR $5.63-14.89 \mathrm{pg} / \mathrm{mL}$; $p=0.350$ ); also, sNfL levels showed no correlation with age in our cohort of young patients $(r=-0.079, p=0.407)$.

CSF measurements for leukocyte count, total protein concentration, Qalb, QIgG, QIgA, QIgM, and OCBs are also presented in table 1 . OCBs were present in $90.2 \%$ of the patients of the whole group and in nearly all of the patients of the MS group (98.9\%).

\section{sNfL level increase is associated with cerebral and spinal relapse manifestation}

sNfL levels tended to be higher during clinical relapse ( $\mathrm{n}=79$, median $9.91 \mathrm{pg} / \mathrm{mL}$, IQR $6.05-17.77 \mathrm{pg} / \mathrm{mL}$ ) in comparison to samples taken from clinically stable patients $(\mathrm{n}=33$, median $8.43 \mathrm{pg} / \mathrm{mL}$, IQR $5.41-11.51 \mathrm{pg} / \mathrm{mL}$ ), but the difference failed to reach significance $(p=0.095)$. We also observed no significant correlation for sNfL levels between the time since symptom onset and spinal tap $(r=0.064, p=0.579)$. However, when stratifying patients for relapse localization, we found that patients with spinal or cerebral relapse showed higher sNfL levels $(\mathrm{n}=58$, median $10.95 \mathrm{pg} / \mathrm{mL}, \mathrm{IQR}$ $6.62-24.61 \mathrm{pg} / \mathrm{mL})$ than those without relapse $(p=0.028)$ and those with $\mathrm{ON}(\mathrm{n}=21$, median $8.43 \mathrm{pg} / \mathrm{mL}$, IQR $5.35-11.86 \mathrm{pg} / \mathrm{mL}, p=0.022$ ) (figure $1 \mathrm{C}$ ).

We did not observe an association between clinical prognostic factors (sensory compared with motor symptoms and complete compared with incomplete remission) and sNfL levels in patients with cerebral relapses. sNfL levels also demonstrated no significant correlation with the Expanded Disability Status Scale (EDSS), independent of whether the cohort was stratified for disease activity at the time of sample collection. Furthermore, there was no significant correlation between any of the inflammation-related CSF parameters and the EDSS, except for Qalb $(r=0.211, p=0.026)$ (table e-1, links. lww.com/NXI/A191). 
Table 1 Patient characteristics: demographic, clinical, MRI, and CSF data

\begin{tabular}{lll}
\hline Parameter & Number (\%) & Median (IQR) \\
\hline Age (y) & & $33.5(28-42)$ \\
\hline Sex & $36(32.1 \%)$ & \\
\hline Male & $76(67.9 \%)$ & \\
\hline Female & & \\
\hline Diagnosis & $21(18.8 \%)$ & \\
\hline CIS & $91(81.2 \%)$ & $14(5-35)$ \\
\hline RRMS & \\
\hline Relapse & $79(70.5 \%)$ & \\
\hline Yes & $33(29.5 \%)$ & \\
\hline No & \\
\hline CEL & $50(44.6 \%)$ & \\
\hline Yes & $62(55.4 \%)$ & \\
\hline No & & \\
\hline Relapse and CEL & & \\
\hline Both & & \\
\hline Neither & & \\
\hline $\begin{array}{l}\text { T2 lesion/CEL } \\
\text { number }\end{array}$ & \\
\hline All patients & & \\
\hline CIS & & \\
\hline RRMS & & \\
\hline Days since & & \\
\hline
\end{tabular}

\section{Clinical manifestation}

\begin{tabular}{|c|c|c|c|}
\hline Spinal & \multicolumn{2}{|c|}{27 (34.2\%) } & \\
\hline Cerebral & \multicolumn{2}{|c|}{31 (39.2\%) } & \\
\hline ON & \multicolumn{2}{|c|}{$21(26.6 \%)$} & \\
\hline EDSS score & & & $2.0(1.0-2.5)$ \\
\hline CSF parameter & Number (\%) & Median (IQR) & $\begin{array}{l}\text { Reference } \\
\text { range }\end{array}$ \\
\hline $\begin{array}{l}\text { CSF leukocyte } \\
\text { count }(/ \mu \mathrm{L})\end{array}$ & & $6(4-10)$ & $\leq 4$ \\
\hline $\begin{array}{l}\text { CSF total } \\
\text { protein } \\
\text { (mg/dL) }\end{array}$ & & $\begin{array}{l}34.1 \\
(27.8-41.7)\end{array}$ & $15-40$ \\
\hline Qalb & & $5.0(3.8-6.1)$ & $\begin{array}{l}\leq 6.5(<40 \text { years }) \\
\leq 8(>40 \text { years })\end{array}$ \\
\hline QIgG & & $4.0(2.8-5.4)$ & $<2.3$ \\
\hline QIgA & & $1.5(1.1-5.4)$ & $<1.3$ \\
\hline QIgM & & $0.4(0.2-0.9)$ & $<0.3$ \\
\hline
\end{tabular}

Table 1 Patient characteristics: demographic, clinical, MRI, and CSF data (continued)

\begin{tabular}{|c|c|c|c|}
\hline CSF parameter & Number (\%) & Median (IQR) & $\begin{array}{l}\text { Reference } \\
\text { range }\end{array}$ \\
\hline \multicolumn{4}{|l|}{ OCB } \\
\hline Positive & 101 (90.2\%) & & \\
\hline Negative & $11(9.8 \%)$ & & \\
\hline
\end{tabular}

Abbreviations: $\mathrm{CIS}=$ clinically isolated syndrome; $\mathrm{CEL}=$ contrast-enhancing lesion; EDSS = Expanded Disability Status Scale; IQR = interquartile range: $\mathrm{OCB}=$ oligoclonal band; ON = optic neuritis; $\mathrm{QIgG}$ = CSF/serum IgG ratio; RRMS = relapsing-remitting MS.

Age, disease duration, and EDSS score are presented as median and IQR: sex, diagnosis, presence of relapse and CELS, and relapse manifestation in absolute numbers and percent.

\section{sNfL level increase is associated with T2 lesion} load and the presence of CELs in MRI

We found a highly significant increase in sNfL levels in the presence of CELs in MRI (patients with CELs: $\mathrm{n}=50$, median $10.98 \mathrm{pg} / \mathrm{mL}$, IQR 7.67-26.11 pg/mL; patients without CELs: $\mathrm{n}=62$, median $7.78 \mathrm{pg} / \mathrm{mL}$, IQR $5.54-11.90 \mathrm{pg} / \mathrm{mL}, p=$ 0.001 ) (figure $2 \mathrm{~A}$ ). Furthermore, sNfL levels correlated with the number of T2 lesions $(r=0.496, p<0.001)$ (figure 2B) and the number of CELs $(r=0.489, p<0.001)$ (figure $2 \mathrm{C}$ ).

To investigate the prognostic value of sNfl, we performed subgroup analyses according to established MRI prognostic factors ${ }^{18}$ in the group of patients with cerebral relapse manifestation $(n=31)$. Supratentorial MRI lesions were found in 28 of these patients (17 with CEL), and infratentorial lesions were found in 19 patients (6 with CEL). There was no association between the presence of infratentorial MRI lesions and sNfL levels. However, after classifying patients according to the number of cerebral $\mathrm{T} 2$ lesions, we found significantly higher sNfL levels in patients with 10 or more T2 lesions $(\mathrm{n}=18$; median $16.33 \mathrm{pg} / \mathrm{mL}$, IQR 7.82-35.68 pg/mL) than in patients with less than 10 lesions $(\mathrm{n}=13$ median $7.50 \mathrm{pg} / \mathrm{mL}$, IQR $5.14-14.52 \mathrm{pg} /$ $\mathrm{mL} ; p=0.028$ ). In addition, we observed that patients with more than 1 CEL $(\mathrm{n}=9$, median $24.58 \mathrm{pg} / \mathrm{mL}$, IQR 9.82-38.77 pg/ $\mathrm{mL})$ had higher sNfL levels than patients with 0 or $1 \mathrm{CEL}(\mathrm{n}=$ 22, median $8.18 \mathrm{pg} / \mathrm{mL}$, IQR 5.61-15.87 pg/mL, $p=0.26$ ).

\section{sNfL levels correlate with CSF markers of acute inflammation}

The CSF leukocyte count was higher during relapse than in clinically stable patients and correlated with sNfL levels $(r=$ $0.288, p=0.002$ ) (figure $3 \mathrm{~A}$ ). In addition, we observed a correlation of the CSF leukocyte count with the number of $\mathrm{T} 2$ lesions $(r=0.209, p=0.027)$ and with the number of CELs $(r=0.215, p=0.023)$ in MRI.

CSF albumin levels $(r=-0.050, p=0.597)$, Qalb $(r=-0.055$, $p=0.562)$, and CSF total protein $(r=0.038, p=0.693)$ were 

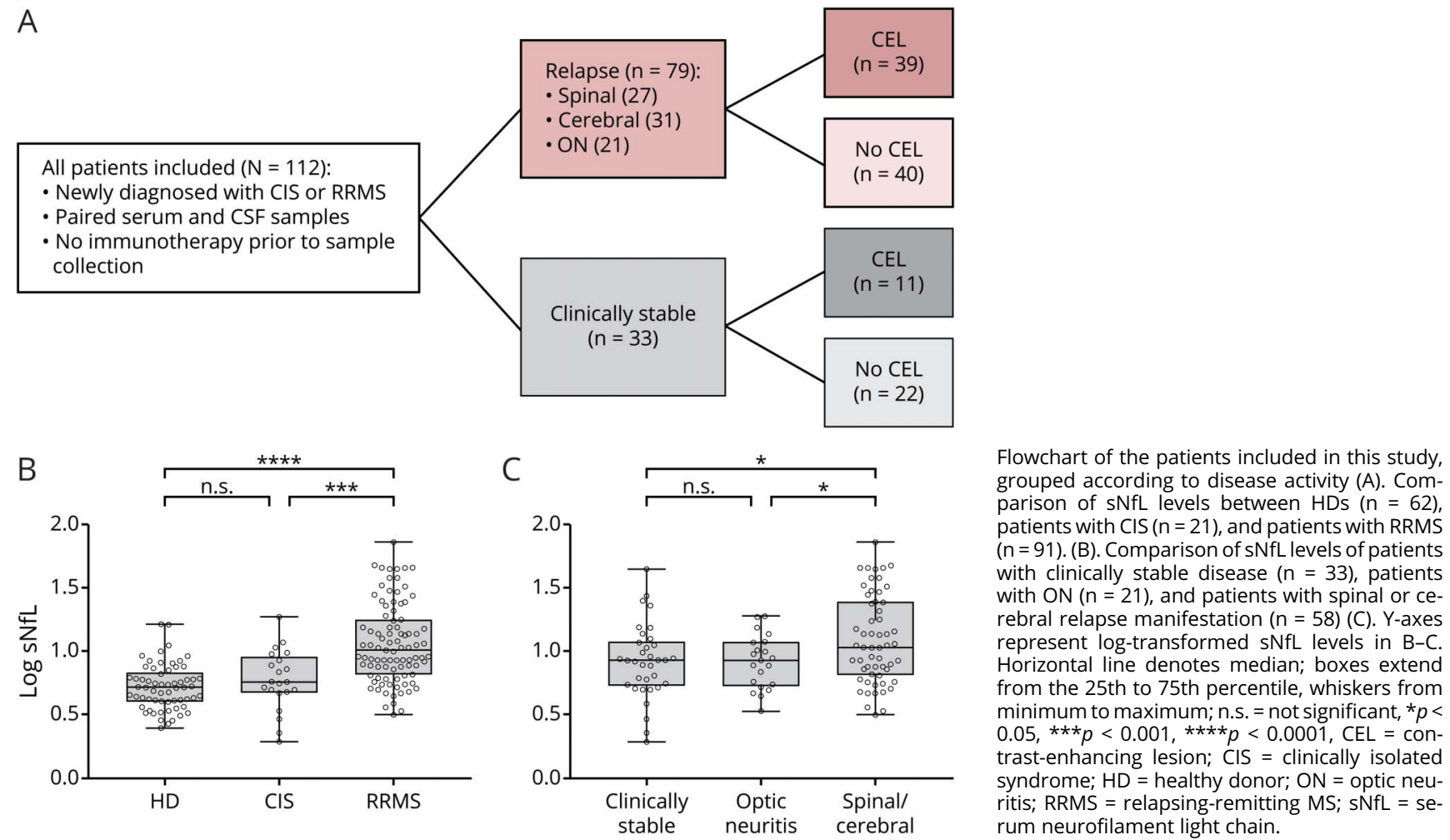

unrelated to sNfL levels independent of the presence of relapse (table e-1, links.lww.com/NXI/A191). However, only 13 patients demonstrated Qalb values above the norm (as per the previously defined cutoff value according to Berlit ${ }^{14}$ ), which may account for the lack of association between Qalb and sNfL levels.

\section{sNfL levels correlate with CSF markers of chronic inflammation}

CSF IgG $(r=0.317, p=0.001)$ (figure 3B) and QIgG $(r=$ 0.344, $p<0.001$ ) (figure $3 \mathrm{C}$ ) moderately correlated with $\mathrm{sNfL}$, and the presence of OCBs was significantly related to increased sNfL levels (OCB positive: $\mathrm{n}=101$, median 9.19 $\mathrm{pg} / \mathrm{mL}$, IQR $6.34-16.38 \mathrm{pg} / \mathrm{mL}$; OCB negative: $\mathrm{n}=11$, median $5.93 \mathrm{pg} / \mathrm{mL}$, IQR $2.93-8.56 \mathrm{pg} / \mathrm{mL}, p=0.001$ ) (figure 3D). Intrathecal fraction of the immunoglobulin subclasses $\operatorname{IgA}(r=-0.030, p=0.753)$ and $\operatorname{IgM}(r=0.128, p=$ $0.182)$ and their $\mathrm{CSF} /$ serum ratios $\mathrm{QIgA}(r=0.106, p=$ $0.267)$ and $\operatorname{QIgM}(r=0.170, p=0.072)$ were unrelated to sNfL levels (table e-1, links.lww.com/NXI/A191).

\section{sNfL levels are predicted by the CSF leukocyte count and CELs in MRI}

Multiple regression analysis using forward selection of CSF parameters and clinical and radiologic parameters of disease activity showed that a total of 2 parameters were retained in the final model for sNfL levels. These included the number of CELs in MRI and the CSF leukocyte count, which, when combined, predicted sNfL levels best. Backward selection for validation showed identical results. The estimated effects of these parameters, their standard error, and statistical significance are detailed in table e-2, links. lww.com/NXI/A191. To conclude the main results, this model states that each increase in the leukocyte count by 1 cell elevates sNfL levels by $0.434 \mathrm{pg} / \mathrm{mL}$ (standardized regression coefficient $\beta$ 0.332) and that each additional CEL in MRI leads to an increase in sNfL levels by $3.390 \mathrm{pg} /$ $\mathrm{mL}(\beta$ 0.532).

\section{Discussion}

In MS, different pathologic processes are linked to overall neuroaxonal damage with a subsequent rise in NfL levels in CSF and serum. These include oxidative stress, mitochondrial damage, ${ }^{19}$ direct $\mathrm{T}$ cell-mediated neuronal damage ${ }^{20}$ and toxic accumulation of synaptic proteins. ${ }^{21}$ It is so far unclear whether the sNfL level increase rather reflects acute focal inflammatory activity or chronic widespread diffuse neurodegenerative processes. Our findings strongly support the view that both contribute to the rise in the sNfL level, as we identified associations with CSF parameters of acute and chronic CNS-intrinsic inflammation. However, markers of acute inflammation outperformed those of chronic inflammation in predicting sNfL levels in our total cohort of mainly active patients, 

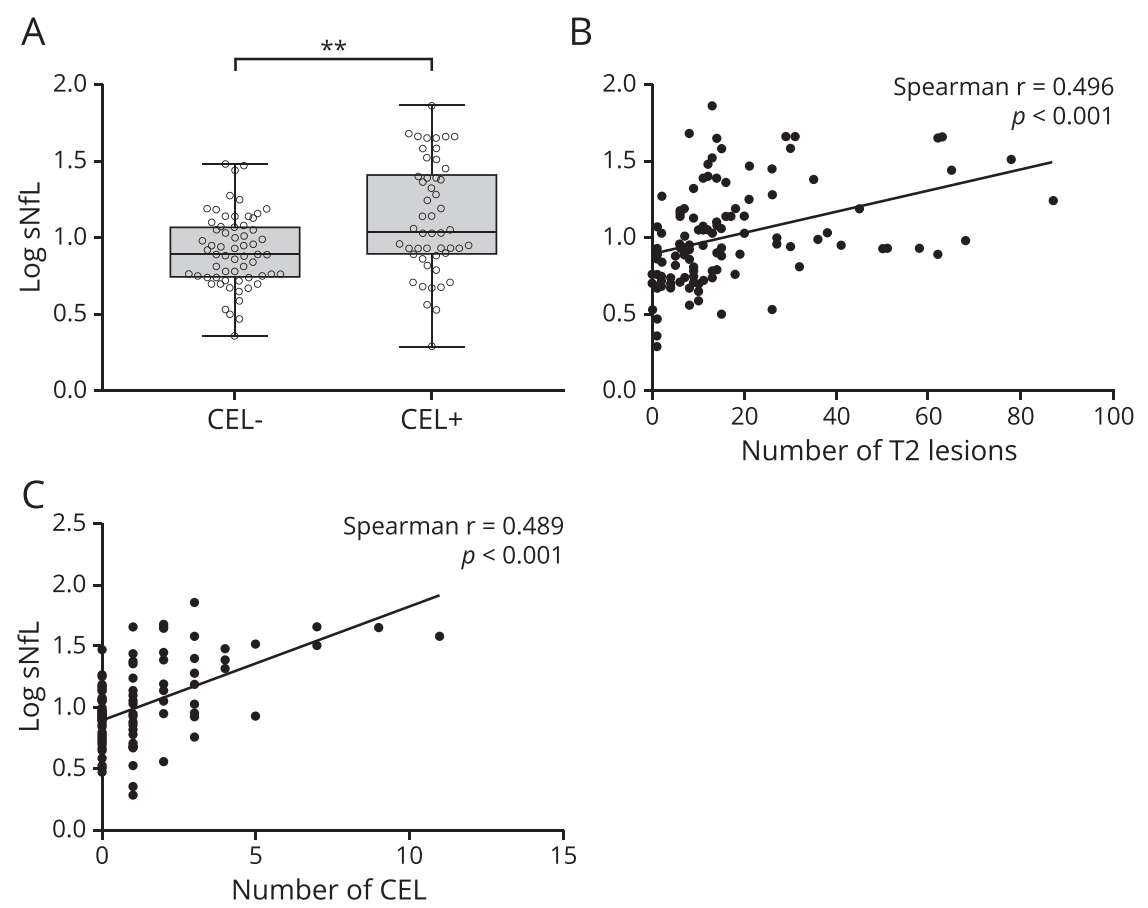

Comparison of sNfL levels between patients with $(n=50)$ and without $(n=62)$ CEL in MRI $(A)$. Correlation of $\mathrm{sNfL}$ levels with the number of $\mathrm{T} 2$ lesions (B) and the number of CELs in MRI (C). Yaxes represent log-transformed sNfL levels in A-C. Horizontal line denotes median; boxes extend from the 25th to 75th percentile, whiskers from minimum to maximum; $* * p<0.01$. CEL = contrast-enhancing lesion; sNfL = serum neurofilament light chain.

who had significantly higher sNfL levels than healthy controls matched for sex and age.

Intrathecal IgG synthesis is an established marker of chronic CSF inflammation. It can be detected by an elevation of
QIgG, the presence of OCBs, or by positive MRZ reaction. Once acquired, it persists mostly unchanged over time and never disappears. ${ }^{11}$ In our cohort, sNfL levels were significantly higher in OCB-positive patients and correlated with CSF IgG levels and QIgG. The finding that OCB-positive

Figure 3 Associations of standard CSF parameters and SNfL levels

A

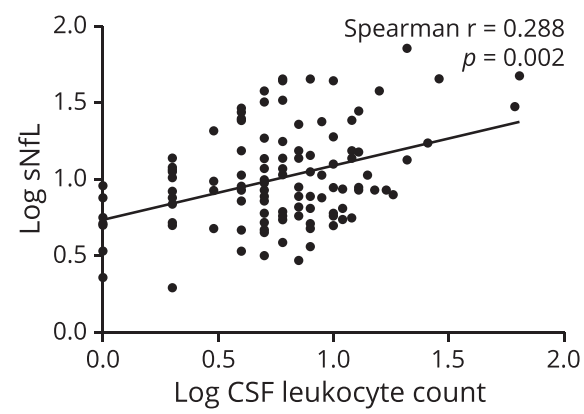

C

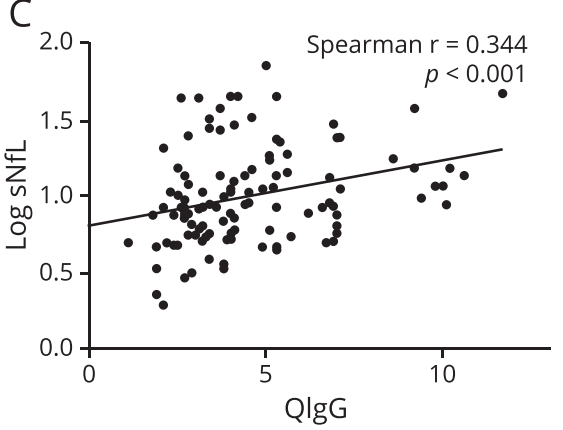

B
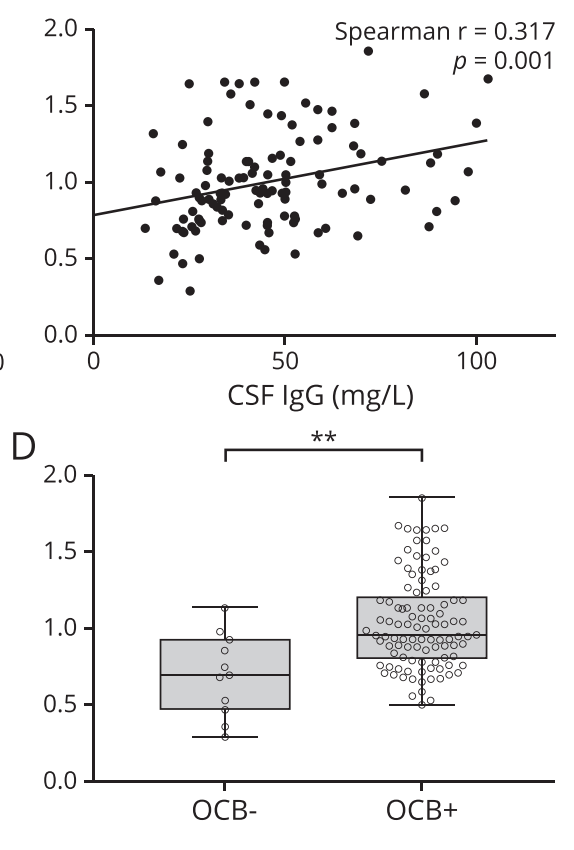

Correlation of sNfL levels with the CSF leukocyte count (A), CSF IgG (B), and QIgG (C). Comparison of sNfL levels between OCB-positive and OCB-negative patients (D). Y-axes represent logtransformed sNfL levels in A-D; in A also, x-axis represents log-transformed CSF leukocyte count. Horizontal line denotes median; boxes extend from the 25th to 75th percentile, whiskers from minimum to maximum; $* * p<0.01$. CEL = contrastenhancing lesion; $\mathrm{CIS}=$ clinically isolated syndrome; IgG = immunoglobulin G; OCB = oligoclonal band; sNfL = serum neurofilament light chain. 
Table 2 Literature overview

\begin{tabular}{|c|c|c|c|c|}
\hline Ref. (no.) & Disease & $\begin{array}{l}\text { No. of } \\
\text { patients }\end{array}$ & $\begin{array}{l}\text { Type of } \\
\text { neurofilament }\end{array}$ & Results \\
\hline \multicolumn{5}{|l|}{ OCB } \\
\hline Present results & MS (CIS and early MS) & 112 & Serum NfL & $\begin{array}{l}\text { Higher sNfL levels in OCB-positive patients than in OCB- } \\
\text { negative patients }\end{array}$ \\
\hline Farina et al. ${ }^{22}$ & MS (disease course not defined) & 90 & CSF NfL & $\begin{array}{l}\text { Higher CSF NfL levels in OCB-positive patients than in OCB- } \\
\text { negative patients }\end{array}$ \\
\hline Kuhle et al. ${ }^{23}$ & MS (CIS, RRMS, SPMS, and PPMS) & 150 & CSF NfH & No association with OCB status \\
\hline \multicolumn{5}{|l|}{$\begin{array}{l}\text { Immunoglobulin } \\
\text { levels }\end{array}$} \\
\hline Present results & MS (CIS and early MS) & 112 & Serum NfL & Correlation with CSF IgG and QIgG \\
\hline $\begin{array}{l}\text { Eikelenboom } \\
\text { et } \text { al. }^{24}\end{array}$ & MS (RRMS, SPMS, and PPMS) & 51 & CSF NfH & No correlation with QIgG \\
\hline Norgren et al. ${ }^{27}$ & MS (RRMS, SPMS, and PPMS) & 99 & CSF NfL & No correlation with QIgG \\
\hline Kuhle et al. ${ }^{23}$ & MS (CIS, RRMS, SPMS, and PPMS) & 150 & CSF NfH & No correlation with CSF IgG, IgA, and IgM levels, nor QIgG \\
\hline \multicolumn{5}{|l|}{ Leukocyte count } \\
\hline Present results & MS (CIS and early MS) & 112 & Serum NfL & Correlation with leukocyte count \\
\hline Norgren et al. ${ }^{27}$ & MS (RRMS, SPMS, and PPMS) & 99 & CSF NfL & Correlation with leukocyte count during relapse \\
\hline Kuhle et al. ${ }^{41}$ & MS (CIS, RRMS, SPMS, and PPMS) & 148 & CSF NfL & $\begin{array}{l}\text { Correlation with leukocyte count in CIS and RRMS, but not in } \\
\text { SPMS and PPMS }\end{array}$ \\
\hline Olesen et al. ${ }^{26}$ & Acute ON & 40 & CSF NfL & $\begin{array}{l}\text { Patients with NfL higher than the median had higher } \\
\text { leukocyte counts than those below }\end{array}$ \\
\hline $\begin{array}{l}\text { Pawlitzki } \\
\text { et al. }{ }^{29}\end{array}$ & PPMS & 50 & CSF NfL & No correlation with leukocyte count \\
\hline \multicolumn{5}{|l|}{ Qalb } \\
\hline Present results & MS (CIS and early MS) & 112 & Serum NfL & No correlation with Qalb \\
\hline Lycke et al. ${ }^{35}$ & RRMS & 60 & CSF NfL & No correlation with Qalb \\
\hline $\begin{array}{l}\text { Malmeström } \\
\text { et al. }{ }^{39}\end{array}$ & MS (RRMS and SPMS) & 66 & CSF NfL & No correlation with Qalb \\
\hline Petzold et al. ${ }^{36}$ & MS (RRMS, SPMS, and PPMS) & 29 & CSF NfH & No correlation with Qalb \\
\hline $\begin{array}{l}\text { Novakova } \\
\text { et al. }{ }^{17}\end{array}$ & MS & 158 & $\begin{array}{l}\text { CSF and serum } \\
\text { NfL }\end{array}$ & No correlation with Qalb \\
\hline $\begin{array}{l}\text { Steinacker } \\
\text { et al. }{ }^{38}\end{array}$ & $\begin{array}{l}\text { Motor neuron disease (ALS and } \\
\text { PLS) }\end{array}$ & 455 & CSF NfL & No correlation with Qalb \\
\hline Kalm et al. ${ }^{37}$ & $\begin{array}{l}\text { Patients with varying degree of } \\
\text { BBB impairment }\end{array}$ & 43 & Serum NfL & No correlation with Qalb \\
\hline Kuhle et al. ${ }^{23}$ & MS (CIS, RRMS, SPMS, and PPMS) & 150 & CSF NfH & $\begin{array}{l}\text { Correlation with Qalb only in patients with RRMS during } \\
\text { relapse }\end{array}$ \\
\hline Kuhle et al. ${ }^{41}$ & MS (CIS, RRMS, SPMS, and PPMS) & 148 & CSF NfL & Correlation with Qalb in CIS, RRMS, and SPMS, but not PPMS \\
\hline Anesten et al. ${ }^{34}$ & HIV-infected patients & 631 & CSF NfL & Correlation with Qalb \\
\hline $\begin{array}{l}\text { Skillbaeck } \\
\text { et al. }{ }^{42}\end{array}$ & Dementias & 1,590 & CSF NfL & $\begin{array}{l}\text { Correlation with Qalb in late-onset Alzheimer disease and } \\
\text { vascular dementia }\end{array}$ \\
\hline
\end{tabular}

Abbreviations: $\mathrm{ALS}=$ amyotrophic lateral sclerosis; $\mathrm{BBB}=$ blood-brain barrier; $\mathrm{CIS}=$ clinically isolated syndrome; $\operatorname{lgG}=$ immunoglobulin $\mathrm{G} ; \mathrm{NfH}=$ neurofilament heavy chain; NfL = neurofilament light chain; $\mathrm{OCB}=$ oligoclonal band; $\mathrm{ON}=$ optic neuritis; $\mathrm{PLS}$ = primary lateral sclerosis; $P$ PMS = primary progressive MS; Qalb = CSF/serum albumin ratio; QIgG = CSF/serum IgG ratio; RRMS = relapsing-remitting MS; sNfL = serum neurofilament light; SPMS = secondary progressive MS.

Comparison of earlier and recent findings concerning associations of neurofilament with CSF markers of chronic (A) and acute (B) CNS-intrinsic inflammation. 
patients demonstrate higher sNfL levels than OCB-negative patients matches an earlier study, which described the same trend for CSF NfL levels. ${ }^{22}$ In contrast, others found no association of neurofilament with intrathecal immunoglobulin synthesis, ${ }^{23,24}$ but it should be noted that these studies only examined CSF neurofilament heavy chain $(\mathrm{NfH})$, which may have different characteristics to NfL.

sNfL levels increase during relapses (compared with stable disease phases) and correlate with the number of CELs in MRI, which suggests exacerbated acute focal inflammation as an underlying cause. In CSF, acute inflammation is reflected by an increase in the leukocyte count and Qalb. Indeed, we found a significant correlation between sNfL levels and the CSF leukocyte count. Comparable results have been seen in previous studies for NfL in CSF. ${ }^{25-27}$ In ocrelizumab-treated patients, corresponding decreases in the CSF leukocyte count and sNfL concentrations have been observed after treatment initiation, leading to the suggestion that levels of CSF inflammatory cells may predict axonal damage. ${ }^{28}$ In progressive MS, on the other hand, no correlation of CSF $\mathrm{NfL}$ with CSF cell count could be found, ${ }^{25,29}$ which indicates a less pronounced acute inflammatory activity in progressive MS.

Albumin is exclusively of extrathecal origin, making its concentration in CSF independent of neuronal homeostasis and any underlying neurodegenerative processes. ${ }^{30}$ Therefore, Qalb is a reliable indicator of BBB integrity. ${ }^{31,32}$ In our study, $\mathrm{Qalb}$ did not correlate with sNfL concentrations. However, as expected in a cohort of patients with MS, the majority of patients (88\%) had Qalb values within normal ranges. We suggest that NfL levels in blood will only be affected by severe disruption of BBB integrity, as described in certain types of dementia ${ }^{33}$ and $\mathrm{HIV}^{34}$ which might explain the inconsistency of previous reports. ${ }^{35-38}$ We provide an overview of former findings concerning the influence of CSF parameters that are relevant in MS diagnostics on various neurofilament isotypes in CSF and serum within table 2.

Although our study showed an association of both acute and chronic neuroinflammatory processes with sNfL levels, markers of acute inflammation, the CSF leukocyte count and the number of CELs in MRI, were better at predicting sNfL levels. This means that the effect of acute inflammatory activity on sNfL may outweigh the effect of underlying chronic inflammation. As sNfL is being discussed intensely as a prognostic biomarker in various neurologic disorders, it will be important to bear in mind the impact of active inflammatory processes on its concentration.

In addition, our data imply that the location of acute inflammation influences sNfL levels, as we found significantly lower sNfL concentrations in patients presenting with ON than in patients with symptoms suggestive of cerebral or spinal inflammation. One possible explanation could be that quantitatively larger CNS compartments are able to release higher absolute quantities of $\mathrm{NfL}$ protein into the CSF and consecutively to the peripheral blood. An earlier study found that CSF NfH levels were nearly twice as high in patients with spinal cord-located relapses than in patients with brain-located relapses, ${ }^{23}$ whereas others found no association of sNfL levels and type of clinical manifestation in $\mathrm{MS}^{39}$ or myelin oligodendrocyte glycoprotein antibodyassociated disorders. ${ }^{40}$ When interpreting the current results, the presence and number of CELs in MRI need to be taken into consideration as possible confounders because patients with cerebral or spinal relapse manifestation presented with CEL more often than those with ON or clinically stable disease. The strict inclusion of only untreated patients, to rule out therapy effects on sNfL levels, is one of the main strengths of our study; however, this also resulted in a relatively small sample size not allowing further subgroup analyses. Further studies are needed to gain deeper insight into the pathophysiologic background behind our observations.

To conclude, our results add to the understanding of neurodegenerative processes in MS by conceptually supporting the hypothesis that axonal damage is caused by acute inflammatory activity and diffuse chronic neuroinflammation, both reflected by an increase in sNfL levels. In addition, episodes of disease activity, and possibly also type of clinical relapse manifestation as well as localization of lesions on MRI, need to be taken into consideration when interpreting $\mathrm{sNfL}$ values in scientific studies and clinical practice.

\section{Acknowledgment}

The authors thank Rosalind Gilchrist for proofreading.

\section{Study funding}

This work was supported by the German Ministry for Education and Research (BMBF), the German Competence Network Multiple Sclerosis (KKNMS), Hertie Foundation (MyLab to SB), an Else Kröner Memorial Stipendium to TU, and the German Research Council (DFG, CRC-TR-128 to FZ).

\section{Disclosure}

S. Engel performed her MD thesis on the topic of the present study. F. Steffen and P. Scholz-Kreisel have nothing to disclose. T. Uphaus received honoraria from Merck Serono and personal fees from Pfizer. F. Zipp has recently received research grants and/or consultation funds from DFG, BMBF, PMSA, MPG, Genzyme, Merck Serono, Roche, Novartis, Sanofi-Aventis, Celgene, ONO, and Octapharma. S. Bittner has received honoraria and compensation for travel from Biogen Idec, Merck Serono, Novartis, Sanofi-Genzyme, and Roche. F. Luessi received consultancy fees from Roche and support with travel cost from Teva Pharma. Go to Neurology. org/NN for full disclosures. 


\section{Publication history}

Received by Neurology: Neuroimmunology \& Neuroinflammation June 7, 2019. Accepted in final form January 8, 2020.

\section{Appendix Authors}

\begin{tabular}{|c|c|c|c|}
\hline Name & Location & Role & Contribution \\
\hline $\begin{array}{l}\text { Sinah } \\
\text { Engel }\end{array}$ & $\begin{array}{l}\text { University Medical } \\
\text { Center of the Johannes } \\
\text { Gutenberg University, } \\
\text { Mainz, Germany }\end{array}$ & Author & $\begin{array}{l}\text { Design and } \\
\text { conceptualization of the } \\
\text { study; acquisition and } \\
\text { analysis of data; and } \\
\text { drafting significant } \\
\text { proportion of the } \\
\text { manuscript }\end{array}$ \\
\hline
\end{tabular}

\begin{tabular}{|c|c|c|c|}
\hline $\begin{array}{l}\text { Falk } \\
\text { Steffen }\end{array}$ & $\begin{array}{l}\text { University Medical } \\
\text { Center of the Johannes } \\
\text { Gutenberg University, } \\
\text { Mainz, Germany }\end{array}$ & Author & Acquisition of data \\
\hline $\begin{array}{l}\text { Timo } \\
\text { Uphaus, } \\
\text { MD }\end{array}$ & $\begin{array}{l}\text { University Medical } \\
\text { Center of the Johannes } \\
\text { Gutenberg University, } \\
\text { Mainz, Germany }\end{array}$ & Author & $\begin{array}{l}\text { Revision of the } \\
\text { manuscript for } \\
\text { intellectual content }\end{array}$ \\
\hline $\begin{array}{l}\text { Peter } \\
\text { Scholz- } \\
\text { Kreisel, } \\
\text { PhD }\end{array}$ & $\begin{array}{l}\text { University Medical } \\
\text { Center of the Johannes } \\
\text { Gutenberg University, } \\
\text { Mainz, Germany }\end{array}$ & Author & Analysis of data \\
\hline $\begin{array}{l}\text { Frauke } \\
\text { Zipp, MD }\end{array}$ & $\begin{array}{l}\text { University Medical } \\
\text { Center of the Johannes } \\
\text { Gutenberg University, } \\
\text { Mainz, Germany }\end{array}$ & Author & $\begin{array}{l}\text { Design and } \\
\text { conceptualization of the } \\
\text { study and revision of the } \\
\text { manuscript for } \\
\text { intellectual content }\end{array}$ \\
\hline
\end{tabular}

\begin{tabular}{|c|c|c|c|}
\hline $\begin{array}{l}\text { Stefan } \\
\text { Bittner, } \\
\text { MD }\end{array}$ & $\begin{array}{l}\text { University Medical } \\
\text { Center of the Johannes } \\
\text { Gutenberg University, } \\
\text { Mainz, Germany }\end{array}$ & Author & $\begin{array}{l}\text { Design and } \\
\text { conceptualization of the } \\
\text { study and drafting } \\
\text { significant proportion of } \\
\text { the manuscript }\end{array}$ \\
\hline $\begin{array}{l}\text { Felix } \\
\text { Luessi, } \\
\text { MD }\end{array}$ & $\begin{array}{l}\text { University Medical } \\
\text { Center of the Johannes } \\
\text { Gutenberg University, } \\
\text { Mainz, Germany }\end{array}$ & Author & $\begin{array}{l}\text { Design and } \\
\text { conceptualization of the } \\
\text { study; acquisition and } \\
\text { analysis of data; and } \\
\text { drafting significant } \\
\text { proportion of the } \\
\text { manuscript }\end{array}$ \\
\hline
\end{tabular}

\section{References}

1. Khalil M, Salzer J. CSF neurofilament light: a universal risk biomarker in multiple sclerosis? Neurology 2016;87:1068-1069.

2. Khalil M, Teunissen CE, Otto M, et al. Neurofilaments as biomarkers in neurological disorders. Nat Rev Neurol 2018;14:577-589.

3. Kuhle J, Barro C, Disanto G, et al. Serum neurofilament light chain in early relapsing remitting MS is increased and correlates with CSF levels and with MRI measures of disease severity. Mult Scler 2016;22:1550-1559.

4. Uphaus T, Bittner S, Groschel S, et al. NfL (neurofilament light chain) levels as a predictive marker for long-term outcome after ischemic stroke. Stroke 2019;50:3077-3084.

5. Barro C, Benkert P, Disanto G, et al. Serum neurofilament as a predictor of disease worsening and brain and spinal cord atrophy in multiple sclerosis. Brain 2018;141: 2382-2391.

6. Dalla Costa G, Martinelli V, Sangalli F, et al. Prognostic value of serum neurofilaments in patients with clinically isolated syndromes. Neurology 2019;92:e733-e41.

7. Engel S, Friedrich M, Muthuraman M, et al. Intrathecal B-cell accumulation and axonal damage distinguish MRI-based benign from aggressive onset in MS. Neurol Neuroimmunol Neuroinflamm 2019;6:e595. doi: 10.1212/NXI.0000000000000595.

8. Thompson AJ, Banwell BL, Barkhof F, et al. Diagnosis of multiple sclerosis: 2017 revisions of the McDonald criteria. Lancet Neurol 2018;17:162-173.

9. Stangel M, Fredrikson S, Meinl E, Petzold A, Stüve O, Tumani H. The utility of cerebrospinal fluid analysis in patients with multiple sclerosis. Nat Rev Neurol 2013;9: 267-276.

10. Deisenhammer F, Zetterberg H, Fitzner B, Zettl UK. The cerebrospinal fluid in multiple sclerosis. Front Immunol 2019;10:726.
11. Bonnan M. Intrathecal IgG synthesis: a resistant and valuable target for future multiple sclerosis treatments. Mult Scler Int 2015;2015:296184.

12. Komori M, Blake A, Greenwood M, et al. Cerebrospinal fluid markers reveal in trathecal inflammation in progressive multiple sclerosis. Ann Neurol 2015;78:3-20.

13. Stüve $\mathrm{O}$, Marra CM, Jerome KR, et al. Immune surveillance in multiple sclerosis patients treated with natalizumab. Ann Neurol 2006;59:743-747.

14. Berlit P. Klinische Neurologie. Heidelberg, Germany: Springer Verlag GmbH; 2011.

15. Gattringer T, Pinter D, Enzinger C, et al. Serum neurofilament light is sensitive to active cerebral small vessel disease. Neurology 2017;89:2108-2114.

16. Bergman J, Dring A, Zetterberg H, et al. Neurofilament light in CSF and serum is a sensitive marker for axonal white matter injury in MS. Neurol Neuroimmunol Neuroinflamm 2016;3:e271. doi: 10.1212/NXI.0000000000000271.

17. Novakova L, Zetterberg H, Sundstrom $\mathrm{P}$, et al. Monitoring disease activity in multiple sclerosis using serum neurofilament light protein. Neurology 2017;89:2230-2237.

18. Tintore M, Rovira À, Río J, et al. Defining high, medium and low impact prognostic factors for developing multiple sclerosis. Brain 2015;138:1863-1874.

19. Friese MA, Schattling B, Fugger L. Mechanisms of neurodegeneration and axonal dysfunction in multiple sclerosis. Nat Rev Neurol 2014;10:225-238.

20. Siffrin V, Radbruch H, Glumm R, et al. In vivo imaging of partially reversible th 17 cellinduced neuronal dysfunction in the course of encephalomyelitis. Immunity 2010;33: 424-436.

21. Schattling B, Engler JB, Volkmann C, et al. Bassoon proteinopathy drives neurodegeneration in multiple sclerosis. Nat Neurosci 2019;22:887-896.

22. Farina G, Magliozzi R, Pitteri M, et al. Increased cortical lesion load and intrathecal inflammation is associated with oligoclonal bands in multiple sclerosis patients: a combined CSF and MRI study. J Neuroinflammation 2017;14:40.

23. Kuhle J, Leppert D, Petzold A, et al. Neurofilament heavy chain in CSF correlates with relapses and disability in multiple sclerosis. Neurology 2011;76:1206-1213.

24. Eikelenboom MJ, Petzold A, Lazeron RH, et al. Multiple sclerosis: neurofilament light chain antibodies are correlated to cerebral atrophy. Neurology 2003;60:219-223.

25. Gaiottino J, Norgren N, Dobson R, et al. Increased neurofilament light chain blood levels in neurodegenerative neurological diseases. PLoS One 2013;8:e75091.

26. Olesen MN, Soelberg K, Debrabant B, et al. Cerebrospinal fluid biomarkers for predicting development of multiple sclerosis in acute optic neuritis: a populationbased prospective cohort study. J Neuroinflammation 2019;16:59.

27. Norgren N, Sundström P, Svenningsson A, Rosengren L, Stigbrand T, Gunnarsson M. Neurofilament and glial fibrillary acidic protein in multiple sclerosis. Neurology 2004; 63:1586-1590.

28. Bar-Or A, Gelfand J, Fiore D, et al. Interim analysis of the OBOE (ocrelizumab biomarker outcome evaluation) study in multiple sclerosis. Neurol Neuroimmunol Neuroinflamm 2018;90(15 suppl)

29. Pawlitzki M, Schreiber S, Bittner D, et al. CSF neurofilament light chain levels in primary progressive MS: signs of axonal neurodegeneration. Front Neurol 2018;9: 1037.

30. Reiber H, Peter JB. Cerebrospinal fluid analysis: disease-related data patterns and evaluation programs. J Neurol Sci 2001;184:101-122.

31. Blennow K, Fredman P, Wallin A, et al. Protein analysis in cerebrospinal fluid. II. Reference values derived from healthy individuals 18-88 years of age. Eur Neurol 1993;33:129-133.

32. Tibbling G, Link H, Ohman S. Principles of albumin and IgG analyses in neurological disorders. I. Establishment of reference values. Scand J Clin Lab Invest 1977;37: 385-390

33. Skillbäck T, Farahmand B, Bartlett JW, et al. CSF neurofilament light differs in neurodegenerative diseases and predicts severity and survival. Neurology 2014;83: 1945-1953.

34. Anesten B, Yilmaz A, Hagberg L, et al. Blood-brain barrier integrity, intratheca immunoactivation, and neuronal injury in HIV. Neurol Neuroimmunol Neuroinflamm 2016;3:e300. doi: 10.1212/NXI.0000000000000300.

35. Lycke JN, Karlsson JE, Andersen O, Rosengren LE. Neurofilament protein in cerebrospinal fluid: a potential marker of activity in multiple sclerosis. J Neurol Neurosurg Psychiatry 1998;64:402-404.

36. Petzold A, Eikelenboom MJ, Keir G, et al. Axonal damage accumulates in the progressive phase of multiple sclerosis: three year follow up study. J Neurol Neurosurg Psychiatry 2005;76:206-211.

37. Kalm M, Bostrom M, Sandelius A, et al. Serum concentrations of the axonal injury marker neurofilament light protein are not influenced by blood-brain barrier permeability. Brain Res 2017;1668:12-19.

38. Steinacker P, Feneberg E, Weishaupt J, et al. Neurofilaments in the diagnosis of motoneuron diseases: a prospective study on 455 patients. J Neurol Neurosurg Psychiatry 2016;87:12-20.

39. Malmeström C, Haghighi S, Rosengren L, Andersen O, Lycke J. Neurofilament light protein and glial fibrillary acidic protein as biological markers in MS. Neurology 2003; 61:1720-1725.

40. Mariotto S, Ferrari S, Gastaldi M, et al. Neurofilament light chain serum levels reflect disease severity in MOG-Ab associated disorders. J Neurol Neurosurg Psychiatry 2019;90:1293-1296.

41. Kuhle J, Plattner K, Bestwick JP, et al. A comparative study of CSF neurofilament light and heavy chain protein in MS. Mult Scler 2013;19:1597-1603.

42. Skillbäck T, Mattsson N, Blennow K, Zetterberg H. Cerebrospinal fluid neurofilament light concentration in motor neuron disease and frontotemporal dementia predicts survival. Amyotroph Lateral Scler Frontotemporal Degener 2017;18 $397-403$ 


\section{Neurology \\ Neuroimmunology \& Neuroinflammation}

\section{Association of intrathecal pleocytosis and IgG synthesis with axonal damage in early MS}

Sinah Engel, Falk Steffen, Timo Uphaus, et al.

Neurol Neuroimmunol Neuroinflamm 2020;7;

DOI 10.1212/NXI.0000000000000679

This information is current as of February 4, 2020

\section{Updated Information \& Services}

\section{References}

Citations

Subspecialty Collections

Permissions \& Licensing

Reprints including high resolution figures, can be found at: http://nn.neurology.org/content/7/3/e679.full.html

This article cites 40 articles, 7 of which you can access for free at: http://nn.neurology.org/content/7/3/e679.full.html\#\#ref-list-1

This article has been cited by 3 HighWire-hosted articles: http://nn.neurology.org/content/7/3/e679.full.html\#\#otherarticles

This article, along with others on similar topics, appears in the following collection(s):

Multiple sclerosis

http://nn.neurology.org//cgi/collection/multiple_sclerosis

Information about reproducing this article in parts (figures,tables) or in its entirety can be found online at:

http://nn.neurology.org/misc/about.xhtml\#permissions

Information about ordering reprints can be found online: http://nn.neurology.org/misc/addir.xhtml\#reprintsus

Neurol Neuroimmunol Neuroinflamm is an official journal of the American Academy of Neurology.

Published since April 2014, it is an open-access, online-only, continuous publication journal. Copyright

Copyright $\odot 2020$ The Author(s). Published by Wolters Kluwer Health, Inc. on behalf of the American Academy of Neurology.. All rights reserved. Online ISSN: 2332-7812.

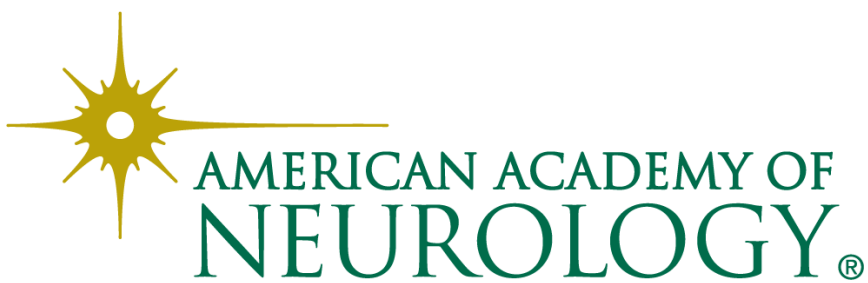

